Original Research Paper

\title{
Nutritional Evaluation and Effectiveness of Detoxified Jatropha curcas Kernel Meal in Finishing Pig Diets on Biogas and Methane Production from Slurry
}

\author{
${ }^{1}$ Bernardo Berenchtein, ${ }^{3}$ Adibe Luiz Abdalla, ${ }^{3}$ Patricia Pimentel Santos Righetto, \\ ${ }^{3}$ Adibe Luiz Abdalla Filho, ${ }^{3}$ André Souza, ${ }^{2}$ Frank George Guimaraes Cruz and ${ }^{2}$ Joao Paulo Ferreira Rufino \\ ${ }^{1}$ Agronomy College, Federal University of South Frontier, 99700-970, Erechim, RS, Brazil \\ ${ }^{2}$ Department of Animal and Plant Production, Sector of Poultry, \\ College of Agrarian Science, Federal University of Amazonas, 69151-424, Manaus, AM, Brazil \\ ${ }^{3}$ University of São Paulo, Centre of Nuclear Energy on Agriculture, 13400-970, Piracicaba, SP, Brazil
}

Article history

Received: 10-11-2015

Revised: $18-08-2016$

Accepted: 19-08-2016

Corresponding Author:

Bernardo Berenchtein

Agronomy College, Federal

University of South Frontier, 99700-970, Erechim, RS, Brazil Tel: +55 5433217050

Email:

bernardo.berenchtein@uffs.edu.br
Abstract: The purpose of this work was to evaluate Phorbol Ester's (PE), Total Fenols (TF), Total Tannins (TT), Condensed Tannins (CT), Saponins Content (SPN), amino acids profiles and apparent digestibility of detoxicated Jatropha curcas meal in finishing pigs diets, as well as biogas and methane production by the manure from cross-bred pigs fed this meal. Apparent digestibility coefficients of Dry Matter (DM), Crude Energy (CE), Crude Protein (CP), Crude Fiber (CF) and Ether Extract (EE) were evaluated. Twenty crossbreed pigs with $70 \pm 1.95 \mathrm{~kg}$ initial weight were allotted in individual metabolic cages, according to body weight in a Complete Randomized Block Design with ten replications per treatment. On the last day of the adaptation phase of the digestibility experiment, the manure were collected and put it in bottles with hydraulic retention time of seven days for further evaluation of biogas and methane produced in liters and liters \% of total solids. The content of PE, TF, TT, CT, SPN, were, respectively, $0.06 \mathrm{mg} / \mathrm{g}, 26.08$ and 10.43 equivalent gram of tannic acid, 0.05 equivalent gram of leucocyanidin and $0.005 \%$. The results of apparent digestibility coefficients were $83.80 \%$ (DM), 3.500 $\mathrm{kcal} / \mathrm{kg}$ (CE), $13.45 \%(\mathrm{CP}), 1.5 \%$ (CF) and $2.3 \%$ (EE). Regarding the generation of biogas and methane of manure from pigs fed detoxified Jatropha curcas meal, biogas production (1201.4, $1089.3 \mathrm{~mL} / \mathrm{g}$ Total Solids) and methane (246.7 and $218.2 \mathrm{~mL} / \mathrm{g}$ Total Solids) from manure weren't significantly different $(\mathrm{p}>0.05)$ between the treatments. So, concludes that detoxicated Jatropha curcas meal is a promising byproduct due its nutritional composition and metabolic response which may be used in finishing pig diets without affecting the generation of renewable energy.

Keywords: Biodiesel, Biogas, By-Product, Finishing Pigs, Nutritional Composition

\section{Introduction}

The feed spend is about $70 \%$ of average costs of swine production for slaughter in Brazil (Girotto and Santos Filho, 2000). In this context, the financial success of any production is directly related to the cost of the feed ingredients. Considering that the diets are constituted basically of corn and soybean meal, which present constant price instability, it's clear the need to search for new alternatives that can replace economically these ingredients. Thus, the research involving the use of alternative feeds, especially the byproducts or waste resulting from the industrial processing of agricultural products and of modern practices of agricultural mechanization, are gaining attention (Gomes, 2006).
Science Publications
(C) 2016 Bernardo Berenchtein, Adibe Luiz Abdalla, Patricia Pimentel Santos Righetto, Adibe Luiz Abdalla Filho, André Souza, Frank George Guimaraes Cruz and Joao Paulo Ferreira Rufino. This open access article is distributed under a Creative Commons Attribution (CC-BY) 3.0 license. 
The growing global concern about the environment and the search for energy renewable sources put the biodiesel on the spotlight of interests. Several countries, including Brazil, are seeking the path of technological domain of biofuel, both in agronomic and industry levels, which should cause a strong impact on the Brazilian economy and on the social inclusion policies of this country (Abdalla et al., 2008).

Brazil has nearly two hundred species of oil plants and palmaceae for oil production and biodiesel (Beltrão, 2006). Jatropha curcas is considered promising for used in animal feed due its high oil content (25-40\%), higher than the other oilseeds used in the biofuels market (Arruda et al., 2004).

The production of biodiesel generates some byproducts, which can be the focus of more detailed analysis. The use of Jatropha curcas meal in animal feed arouses the interest of many researchers and it could be used in animal feed, provided that appropriate treatments should be performed for the reduction or elimination of bioactive molecules, such as phorbol esters (Neiva Junior et al., 2007).

The chemical analysis and feeding tests are the first items to determine the potential and nutritional value of a food to be used on animal nutrition. Different animal species metabolize food differently; being this variation quantified upon the determination their digestibility coefficients. The digestibility of a feed is defined as the skill with which the animal digests and absorbs the nutrients and energy it contains. The digestibility determination of an ingredient is the first concern when it comes to evaluating their potential for inclusion in rations for animal (Pezzato et al., 2004). Thus, the purpose of this study was to determine the chemical composition, phorbol esters, total phenols, total tannins, condensed tannins, saponins content, amino acid profile, the apparent digestibility of detoxified Jatropha curcas meal (Jatropha curcas L.) for finishing pigs and to evaluate the biogas and methane generation from the manure obtained from pigs fed this product.

\section{Materials and Methods}

\section{Chemical Analyses}

This work was development in the premises of the Animal Nutrition Laboratory of the Nuclear Energy in Agriculture Center (CENA) of University of São Paulo, São Paulo, Brazil. The Detoxified Jatropha curcas Meal (DJCM) used was collected in a biodiesel industry producer, being later industrially detoxified.

The chemical composition analysis were performed according to AOAC (2005) and the amino acid profile obtained by HPLC process. The concentrations of phorbol esters were analyzed following the method by Makkar et al. (1997), the contents of total phenols and total tannins analyzed by Folin-Ciocalteu, condensed tannins (proanthocyanidins) by the butanol-HCl method (Makkar, 2000) and the concentration of saponins analyzed according to Makkar et al. (2007).

\section{Apparent Digestibility and Experimental Set Up}

Ten crossbred pigs, barrows, with average weight of $70 \pm 1,95 \mathrm{~kg}$ were used, distributed in a randomized block design in function of body weight in two treatments: The Reference Diet (RD) and Test Diet (TD), with five replicates (blocks), with an animal for metabolic cage (experimental unit).

Before the experimental period, feed intake tests to determine the maximum level of inclusion of DJCM in reference diet were performed, so that feed intake was not prejudice in the excreta collection period. Thus, the TD was composed of $92.3 \%$ of the RD and $7.7 \%$ of DJCM. The reference diet was formulated in accordance with the requirements proposed by Rostagno et al. (2005) as shown in Table 1.

The partial excreta collection method was used and chromic oxide $\left(\mathrm{Cr}_{2} \mathrm{O}_{3}\right)$ employed as a marker added to the experimental diets at a concentration of $0.05 \%$. The animals were weighed before and after the trial, which lasted thirteen days with seven days of adaptation and measurement of voluntary feed intake, three days for adaptation and maintenance of flow of marker and three days of excreta collection. The quantities of diets supplied were calculated according to the metabolic weight $\left(\mathrm{PV}^{0.75}\right)$ and a proportion of 1:1 water and diet was supplied to the animals twice a day, at 08:00 and 16:00.

In adaptation period, the animals were encouraged to consume the maximum of feed aiming at avoiding leftovers and in the collection period the quantities of diets in each treatment were based on lower consumption among the animals of the block, obtained in the adaptation period.

From the average feed intake in the adaptation period, was established the Amount Restricted Feed (ARF) provided during the days of excreta collection, according to the following calculations:

$$
\text { ARF }=I * \text { Metabolic Weight }
$$

Where:

$$
\begin{aligned}
\text { ARF } & \text { Amount restricted feed }(\mathrm{kg}) \\
\mathrm{I} & \text { Index }=\text { average feed intake of } \\
& \text { the days }(\mathrm{kg}) / \text { Metabolic weight } \\
\text { Metabolic Weight }(\mathrm{kg})= & {\text { (live weight })^{0.75}}
\end{aligned}
$$

The index (I) was calculated for all animals, however, was adopted the lowest value of I, to calculate the ARF. Although the I value standardization, ARF were evaluated individually, also calculated being in function on the weight of each animal. Water was provided ad libitum throughout the experimental period. 
Excreta samples from the rectum were collected twice daily (08:00 and 16:00) being these immediately placed in plastic bags, identified and frozen. After, these samples were thawed and homogenized in a single composite sample. These were dried in trays at appropriate ovens of forced air circulation at $65^{\circ} \mathrm{C}$ for 72 $\mathrm{h}$, milled in mill through sieve riddled of $1 \mathrm{~mm}$. The excreta and feed samples were analyzed for dry matter, crude energy, crude protein, crude fiber, ether extract and chromium oxide content.

Chromium oxide percentage in the samples was done in Instrumentation Nuclear Laboratory of Nuclear Energy in the Agriculture Center (CENA) of University of São Paulo by technique of X-ray fluorescence for dispersive energy (Zucchi and Nascimento Filho, 1995; Nascimento Filho et al., 1997). The apparent digestibility coefficients of RD and TD were calculated according to Serrano (1989) and from this, determined the apparent digestibility coefficients of dry matter, crude energy, crude protein, crude fiber and ether extract of DJCM using the equation proposed by Matterson et al. (1965).

\section{Biogas and Methane Production}

On the last day of adaptation phase to the cage in digestibility experiment, the pigs manure were collected and added in proportion of $250 \mathrm{~mL}$ of excreta's, $250 \mathrm{~mL}$ of urine and $615 \mathrm{~mL}$ of water in PET bottles previously identified with total volume of $3,125 \mathrm{~mL}$ with rubber stoppers adapted to screw caps, sealed with silicone glue to prevent the gas produced was lost, placed in oven of forced ventilation at $40^{\circ} \mathrm{C}$ without agitation and with
Retention Hydraulic Time (RHT) of seven days. These conditions were observed by Souza et al. (2005) as being ideal for biogas production by pigs manure, simulating the conditions of a batch bio digester, without continuous flow of effluents, for biogas and methane $\left(\mathrm{CH}_{4}\right)$ quantification. Two treatments were used, RD and TD (7.7\% inclusion of DJCM), through ten bottles (replicates) for each treatment.

Each bottle was dimensioned for storing two liters of biogas and permit the biogas produced quantitation, through the use of a pressure gauge (transducer-model PDL800LANA-CENA/USP) adapted of Theodorou et al. (1994) and graduated syringes, where two first days was held instrument calibration and preparation of the response curve. During the seven days, the pressure exerted by gases was measured for subsequent determination of the biogas volume of each bio digester (bottle). After each time of reading of gases production, a gas aliquot was stored in test tubes previously identified and subjected to vacuum where the determination of the methane levels $\left(\mathrm{CH}_{4}\right)$ were done using a gas chromatograph model CG2014 GAS CHROMATOGRAPHA (Shimadzu). The equipment calibration was performed with standard gas supplied by White Martins. In addition, total solids levels (AOAC, 2005) of the waste incubated in each bio digester were evaluated. Considering the effective bio digester volume of $2,000 \mathrm{~mL}$, the biogas and methane volumetric total production were determined, as well as daily thereof production in $\mathrm{mL} / \mathrm{g}$ of total solids. The design was randomized blocks, with two treatments and ten replicates per treatment.

Table 1. Nutritional composition of the reference diet

\begin{tabular}{lr}
\hline Ingredients & Reference ration \\
\hline Corn & 81.35 \\
Soybean meal (45\%) & 16.07 \\
Di calcium phosphate & 0.82 \\
Limestone calcitic $^{1}$ Vitamin C supplement $^{2}$ & 0.65 \\
Mineral supplement $^{2}$ & 0.40 \\
Salt & 0.10 \\
L-Lysine (78\%)(HCl) & 0.40 \\
Copper sulphate (25\%) & 0.15 \\
Nutritional calculated values & 0.06 \\
Metabolizable energy, kcal/kg & 3230.00 \\
Crude protein, \% & 14.19 \\
Digestible methionine, \% & 0.22 \\
Digestible methionine + cystine, \% & 0.45 \\
Total lysine, \% & 0.76 \\
Digestible lysine, \% & 0.68 \\
Digestible threonine, \% & 0.45 \\
Calcium, \% & 0.53 \\
Total phosphorus, \% & 0.44 \\
Available phosphorus, \% & 0.25
\end{tabular}

${ }^{1}$ Amountsper kg diet: Vit. A-2520 UI; vit. D3-540 IU; vit. E -9.9 IU; vit. K3-0.72 mg; thiamine-404 mcg; riboflavin-1.98 mg; pyridoxine-404 mcg; vit. B12-8.1 mcg; folicacid-225.2 mcg; Pantothenic Acid-6.3 mg; Niacin-12.6 mg; growth promoter-10 mg; Se0.24 mg; ${ }^{2}$ Amountsper kg diet: $\mathrm{Cu}-9$ mg; Fe -81 mg; I -0.9 mg; Mn-54 mg; Zn-135 mg 


\section{Statistical Data Analysis}

The statistical analysis of the data was performed using SAS ${ }^{\circledR}$ v.9.2 (Statistical Analysis). SAS LAB procedure was used to verify data adequacy to the linear model and then the variables obtained were submitted to analysis of variance using the PROC GLM.

\section{Results and Discussion}

In relation to bioactive molecules analyzed in DJCM (Table 2), phorbol esters content $(0.06 \mathrm{mg} / \mathrm{g})$ is lower than that found for Makkar et al. (1997), who evaluated the content of these in nontoxic to the animals varieties $(0.11 \mathrm{mg} / \mathrm{g})$, by Rakshit et al. (2008) evaluating DJCM in diet for rats $(0.2 \mathrm{mg} / \mathrm{g})$.

Chivandi et al. (2006), evaluating the effect of different methods of detoxification in the Jatropha curcas meal with $0.8 \mathrm{mg} / \mathrm{g}$ of phorbol esters, observed significant losses in pigs blood parameters. The phorbol esters mimic the Diacylglycerol (DAG) action, inactivating the protein kinase $\mathrm{C}$, which regulates different pathways signal of translation and other metabolic activities by acting as co-carcinogen and causing cellular and biochemical effects in many different animal species (Goel et al., 2007) and studied extensively in different animal models like goats, sheep, mice, rats and fish when fed with phorbol estercontaining feeds (Adam and Magzoub, 1975; Makkar et al., 1998). The phorbol esters content depends on the oil residue present on pie or meal after the processing (Rakshit et al., 2008), which justifies the values obtained in this study, since this is a specific research and the oil was almost completely extracted to obtain the meal and this passed over by the detoxification process.

The total phenols and total tannins values are similar to those reported by Makkar et al. (1998), but the content of condensed tannins is different from those observed by the same authors, that evaluating toxic and nontoxic varieties of Jatropha curcas not found condensed tannins in both varieties. It is important noting that there are factors that affect the tannin concentration in plants, among which stand out climate, plant mineral nutrition and growth stage (Waterman and Mole, 1994).

Tannins can affect negatively the feed intake, digestibility and the performance of animals. These effects depend greatly on the amount, the tannin type ingested and the animal tolerance, being more prominent in non-ruminants. Levels above $1 \%$ of condensed tannins in the diet, well above the values obtained in this study, affect mainly the intake, digestibility of protein and of the essential amino acids (McDonald et al., 1995).

The saponins content observed $(0.005 \%)$ is similar to those reported by Makkar et al. (1998) assessed the nutritional content of seeds and meal of detoxified Jatropha curcas from non-toxic varieties in Mexico and even to those observed by Belewu and Sam (2010) who evaluated the content of different bioactive molecules of the DJCM by different microorganism's strains. The saponins are glycosides present in most part of the diets ingredients for animals. Is characterized by a bitter taste, capacity to form foam in aqueous solution, cause hemolysis and, also, of complexing in steroid. Moreover, their antinutritional effects also are related to changes in the permeability of the intestinal mucosa, inhibiting the transport of some nutrients, facilitating the absorption of other compounds (Francis et al., 2001).

In relation to amino acids analyzed of the DJCM (Table 3), the contents were slightly below those found by Makkar et al. (1998), that reported values of arginine $(12.9 \%)$, cystine $(1.58 \%)$, phenylalanine $(4.89 \%)$, histidine $(3.08 \%)$, Isoleucine $(4.85 \%)$, leucine $(7.5 \%)$, lysine $(3.4 \%)$, methionine $(1.76 \%)$, tyrosine $(3.78 \%)$, threonine $(3.59 \%)$, tryptophan $(1.31 \%)$, valine $(5,3 \%)$. According to these authors, the chemical composition of Jatropha curcas varies depending on the source, being similar to soybean meal, presenting only minor amount of lysine and higher value of sulfur amino acids.

The CE of DJCM determined in this study was 5,900 $\mathrm{kcal} / \mathrm{kg}$ and the apparent digestibility coefficient of energy was $59.6 \%$, from the value of digestible apparent energy of $3,500 \mathrm{kcal} / \mathrm{kg}$ (Table 4). Thus, DJCM can be considered an excellent source of energy, since the digestible energy value $(3,500 \mathrm{kcal} / \mathrm{kg})$ is similar to corn (Rostagno et al., 2005) and other cereals considered energy sources, such as the low tannin sorghum, triticale and the wheat meal, which have average digestible energy values of 3,794 (Ferreira et al., 1997), 3,236 (Furlan et al., 1999; Radecki and Miller, 1990) and $3,300 \mathrm{kcal} / \mathrm{kg}$ (Lima and Viola, 2001), respectively.

Regarding the CP content and their digestibility, value of $51.1 \%$ were observed, result considered excellent for protein sources. However, the apparent digestibility coefficient was only $26.3 \%$ with digestible protein value of $13.5 \%$. These values are inferior when compared with digestible protein values of other oilseed meals considered as protein sources and oil source for biodiesel production.

In Turkey, Boguhn et al. (2010) evaluated the digestibility of DJCM amino acids and concluded that for young turkeys is higher compared with other ingredients to animals of the same species, therefore, can use it as an ingredient in diet.

In addition to soybean meal, worldwide used as ingredient protein in the animal diets, some foods considered by-products, such as cotton meal, peanut meal and canola meal, have respectively 25, 44 and $26 \%$ of digestible protein for pigs (Rostagno et al., 2005). 
Table 2. Dry matter content and bioactive molecules found in detoxified Jatropha curcas meal (DJCM)

\begin{tabular}{lr}
\hline Components & DJCM \\
\hline Dry Matter $\left(100^{\circ} \mathrm{C}\right), \%$ & 96.500 \\
Phorbol esters, $\mathrm{mg} / \mathrm{g}_{\text {Phenols total }^{2},}$ & 0.060 \\
Total tannins $^{2}$. & 26.080 \\
Condensed tannins $^{3}$, & 10.430 \\
Saponins, \% & 0.050 \\
\hline
\end{tabular}

${ }^{1}$ Analyses carried at the Animal Nutrition Laboratory of Nuclear Energy in Agriculture Center of University of São Paulo, São Paulo, Brazil (LANA/CENA/USP) and in the Animal Production Center in the Tropics and Subtropics, University of Hohenheim, Stuttgart, Germany.

${ }^{2}$ Results in equivalent gram of tannic acid.

${ }^{3}$ Results in equivalent gram of leucocyanidin.

Table 3. Amino acidic profile in detoxified Jatropha curcas meal (DJCM) ${ }^{1}$

\begin{tabular}{lc}
\hline Amino acid ${ }^{1}$ \% in DM & DJCM \\
\hline Alanine & 2.19 \\
Arginine & 5.94 \\
Aspartic acid & 4.16 \\
Glycine & 1.98 \\
Isoleucine & 1.93 \\
Leucine & 2.93 \\
Glutamic acid & 7.44 \\
Lysine & 1.24 \\
Cystine & 0.71 \\
Methionine & 0.76 \\
Phenylalanine & 1.81 \\
Tyrosine & 1.28 \\
Threonine & 1.53 \\
Tryptophan & 0.50 \\
Proline & 1.83 \\
Valine & 2.30 \\
Histidine & 1.09 \\
Serine & 2.14 \\
\hline Values obtaned & \\
\hline
\end{tabular}

${ }^{\mathrm{T}}$ Values obtained by means of HPLC in the animal nutrition laboratory of the CBO Analysis, Campinas/SP, Brazil.

Table 4. Chemical composition, crude energy, apparent digestibility coefficients (CDap) and apparent digestible nutrient (NDap) of Detoxified Jatropha Curcas Meal (DJCM) for finishing pigs

\begin{tabular}{lccr}
\hline Centesimal fractions & Chemical compostition & CDap, \% & NDap \\
\hline Dry Matter, \% & 96.5 & 86.8 & 83.80 \\
Crude energy, kcal/kg & $5,900.0$ & 59.6 & $3,500.00$ \\
Crude Protein, \% & 51.1 & 26.3 & 13.50 \\
Crude fiber, \% & 4.3 & 34.5 & 1.50 \\
Ether Extract, \% & 21.9 & 10.2 & 2.24 \\
\hline
\end{tabular}

${ }^{1}$ Analyses carried at the Animal Nutrition Laboratory of Nuclear Energy in Agriculture Center of University of São Paulo, São Paulo, Brazil (LANA/CENA/USP).

Table 5. Biogas and methane production in $\mathrm{mL} / \mathrm{g}$ of total solids of pigs manure fed with Reference Diet (RD) and reference diet + $8 \%$ DJCM $(\mathrm{RD} \%)$

\begin{tabular}{lllll}
\hline & RD & RD8\% & P & CV (\%) \\
\hline Biogas (mL/g of TS) & $1,201.37$ & $1,089.27$ & Ns & 25.2 \\
Methane (mL/g of TS) & 246.71 & 218.16 & Ns & 29.8 \\
\hline
\end{tabular}

P-coefficient of probability. CV-coefficient of variation

Thus, it's evident that DJCM, while possessing high level of crude protein in its composition, this nutrient is hardly been tapped by the pigs. Probably, the presence of bioactive molecules, such as protease inhibitors, saponins, tannins and phytates impaired the nutrient digestibility, which shows that the meal used in this study wasn't fully 
detoxified. Another possible explanation for the low crude protein digestibility coefficient observed in this study, may be due to low inclusion of the DJCM in the diet due low acceptance by the animals.

Regarding the crude fiber content, the value of $4.3 \%$ was observed with apparent digestibility coefficient of $34.5 \%$ with the digestible fiber value of $1.1 \%$. It's verified that the DJCM has lower content of crude fiber and digestibility higher when compared to the values obtained in cotton meal (25\%) (Rostagno et al., 2005). In relation to the ether extract content, the value of $21.9 \%$ were observed with the digestibility apparent coefficient of $10.2 \%$, providing the digestible ether extract value of $2.2 \%$. The nutritional value of some foods depends mainly on the content, nutrients biological availability and further the presence and levels of toxic substances or bioactive molecules, which can alter this composition or become unavailable some of these nutrients (Pezzato, 1995).

The mean values of volumetric cumulative production per gram of biogas and methane in total solids are shown in Table 5. The production curves of biogas and methane ( $\mathrm{mL} / \mathrm{g}$ of total solids) by the pigs manure, well as the accumulated production of biogas and methane $(\mathrm{mL})$ are shown in the graphs 1 and 2, respectively.

In studies of Miranda (2005) average potentials of biogas production of $0.489 ; 0.566$ and $0.768 \mathrm{~m}^{3} / \mathrm{kg}$ of Total Solids (TS) were verified in biodigesters supplied with excretas of pigs, subjected to temperature $35^{\circ} \mathrm{C}$ and Retention Hydraulic Time (RHT) of 30 days, these results are lower than those found in this study.

The biogas $(1201.4 ; 1089.3 \mathrm{~mL} / \mathrm{g}$ of total solids) and methane (246.7 and $218.2 \mathrm{~mL} / \mathrm{g}$ of total solids) production from the finishing pigs manure fed with reference diet and diet containing DJCM are compatible with those observed by Souza et al. (2005), evaluated different retention hydraulic times and incubation temperatures of pigs manure. The methane proportion in relative to the biogas generated was of 20.5 and $20.35 \%$ for the treatments RD and RD8\%, values well below of 60 to $70 \%$, theorized by Miranda (2009) as normal. This happened, probably, due to the low retention hydraulic time (7 days) exercised in this study, corroborating Lucas Junior (1994) that assessing the effects of retention hydraulic times of 50,30, 20 and 15 days, in the case of bio digestion anaerobic of pigs manure, found that the highest efficiency is obtained at RHT of 30 days, with worst use of the manure in the RHT of 15 days.

\section{Conclusion}

Detoxified Jatropha curcas Meal (DJCM) can be used in finishing pig diets without affecting the generation of renewable energy by its manure. Although the DCJM has shown low apparent digestibility of the nutrients for pigs, the biogas and methane generation wasn't compromised.

\section{Acknowledgments}

The authors would like to thank State of Sao Paulo Research Foundation (São Paulo, Brazil) for financial support.

\section{Author Contributions}

All the authors equally contributed in this work and the article.

\section{Conflict of Interest}

There is no conflict of interest.

\section{References}

Abdalla, A.L., J.C. Silva Filho, A.R. Godoi, C.A. Carmo and J.L.P. Eduardo, 2008. Utilização de subprodutos da indústria de biodiesel na alimentação de ruminantes. Rev. Bras. de Zoot, 37: 258-260. DOI: $10.1590 / \mathrm{S} 1516-35982008001300030$

Adam, S.E.I. and M. Magzoub, 1975. Toxicity of Jatropha curcas for goats. Toxicology, 4: 347-354. PMID: 1154432

Arruda, F.P., N.E.M. Beltrão, A.P. Andrade, W.E. Pereira and L.S. Severino, 2004. Cultivo de pinhão-manso (Jatropha curcas L.) como alternativa para o SemiÁridonordestino. Rev. Bras. Oleaginosas Fibrosas, 8: 789-799.

AOAC, 2005. Association of official analytical chemists. Official methods of Analysis. Washington, DC.

Belewu, M.A. and R. Sam, 2010. Solid state fermentation of Jatropha curcas kernel meal: Proximate composition and antinutritional components. J. Yeast Fungal Res., 1: 44-46.

Beltrão, N.E.M., 2006. Consideraçõesgeraissobre o pinhãomanso (Jatropha curcas L.) e a necessidadeurgente de pesquisas, desenvolvimento e inovações tecnológicas para estas plantas nas condições brasileiras. Ministério do Desenvolvimento Agrário-Secretaria da Agricultura Familiar, Brasília, DF.

Boguhn, J., H.P.S. Makkar, K. Becker and M. Rodehutscord, 2010. Amino acid digestibility of detoxified jatropha kernel meal in turkeys. Proceedings of the 13th European Poultry Conference, Aug. 23-27, Tours, France, pp: 476-476.

Chivandi, E., K.H. Erlwanger, S.M. Makuza, J.S. Read and J.P. Mtimuni, 2006. Effects of dietary Jatropha curcas meal on percent packed cell volume, serum glucose, cholesterol and triglyceride concentration and Alpha-Amylase activity of weaned fattening pigs. Res. J. Anim. Vet. Sci., 1: 18-24. 
Ferreira, W.M., A.L. Sartori, G.S. Santiago and J.A.F. Veloso, 1997. Apparent digestibility of ramie hay (Boehmeria nivea, G), pigeon pea hay (Cajanus cajan, L.), perennial soybean hay (Glycine wightii V.) and bean husk (Phaseolus vulgaris, L.) on growing rabbits. Arq. Bras. Med. Vet. Zootec., 49: 465-472.

Francis, G., H.P.S. Makkar and K. Becker, 2001. Antinutritional factors present in plant-derived alternate fish feed ingredients and their effects in fish. Aquaculture, 199: 197-227. DOI: $10.1016 / \mathrm{S} 0044-8486(01) 00526-9$

Furlan, R.L., M. Macari and V.M.B. Moraes, 1999. Alterações hematológicas e gasométricas em diferentes linhagens de frangos de corte submetidos ao estresse calórico agudo. Revista Brasileira de Ciência Avícola, 1: 77-84.

Girotto, A.F. and J.J. Santos Filho, 2000. Custo de Produção de Suínos. 1st Edn., Embrapa Semi-Árido, Concórdia, pp: 36.

Goel, G., H.P.S. Makkar, G. Francis and K. Becker, 2007. Phorbol esters: Structure, biological activity and toxicity in animals. Int. J. Toxicol., 26: 279-288. DOI: $10.1080 / 10915810701464641$

Gomes, J.D.F., 2006. Efeitos do incremento da fibra em detergente neutro na dieta de suínos sobre a morfologia dos órgãos digestivos e não digestivos. Brazilian J. Vet. Res. Anim. Sci., 43: 202-209.

Lima, G.J.M.M. and E.S. Viola, 2001. Ingredientes Energéticos: Trigo e Triticale na Alimentação Animal. In: Simpósio Sobre Ingredientes $\mathrm{Na}$ Alimentação Animal, Campinas CBNA, pp: 33-61.

Lucas Junior, J., 1994. Algumas considerações sobre o uso do estrume de suínos como substrato para três sistemas de biodigestores anaeróbios. Universidade Estadual Paulista, Jaboticabal.

Makkar, H.P.S., 2000. Quantification of tannins in tree foliage. FAO, IAEA, Vienna.

Makkar, H.P.S., A.O Aderibigbe and K. Becker, 1998. Comparative evaluation of non-toxic and toxic varieties of Jatropha curcas for chemical composition, digestibility, protein degradability and toxic factors. Food Chem., 62: 207-215. DOI: $10.1016 / \mathrm{S} 0308-8146(97) 00183-0$

Makkar, H.P.S., K. Becker, F. Sporer and M. Wink, 1997. Studies on nutritive potential and toxic constituents of different provenances of Jatropha curcas. J. Agric. F. Chem., Easton, 45: 3152-3157. DOI: $10.1021 / j \mathrm{j} 970036 \mathrm{j}$

Makkar, H.P.S., P. Siddhuraju and K. Becker, 2007. Plant Secondary Metabolites. 1st Edn., Humana Press, Clifton, ISBN-10: 1588299937, pp: 130.

Matterson, L.D., L.M. Potter, M.W. Stutz and E.P. Singsen, 1965. The metabolizable energy of feed ingredients for chickens. Res. Rep., 7: 11-14.
McDonald, P., R.A. Edwards, J.F.D. Greenhalgh and C.A. Morgan, 1995. Animal Nutrition. 5th Edn., Acribia, Zaragoza, pp: 576.

Miranda, C.R., 2005. Avaliação de estratégias para sustentabilidade da suinocultura. PhD., Thesis, Universidade Federal de Santa Catarina.

Miranda, A.P., 2009. Suínos em diferentes fases de crescimento alimentados com milhoou sorgo: Desempenho, digestibilidade e efeitos na biodigestão anaeróbia. Tese (Doutorado em Zootecnia) Faculdade de Ciências Agrárias e Veterinárias, UniversidadeEstadualPaulista Julio de MesquitaFilho, Jaboticabal.

Nascimento Filho, V.F., A.L. Abdalla, C.M. Korndorfer, 1997. Sensibilidadesanalíticas de Diferentesmodos de Excitaçãoemfluorescência de Raios X Paramedida de Traçadoresemfezes de Animais. In: Encontro Científico dos Pós-Graduandos do Cena/usp, Piracicaba. Resumos... Piracicaba: CENA/USP.

Neiva Junior, A.P., E.H.C.B. Van Cleef, R.M.P. Pardo, J.C. Silva Filho and P. Castro Neto et al., 2007. Subprodutos Agroindustriais do Biodiesel na Alimentação de Ruminantes. In: Congresso Da Rede Brasileira De Tecnologia De Biodiesel, Brasília, DF, Anais... Brasília, DF: REDEBIO.

Pezzato, L.E., 1995. Alimentosconvencionais e NãoConvencionaisdisponíveisparaindústria da Nutrição de Peixes no Brasil. In: Simpósio Internacional Sobre Nutrição De Peixes E Crustáceos, Campos do Jordão. CBNA, Campos do Jordão, pp: 33-52.

Pezzato, L.E., E.C. Miranda, M.M. Barros, W.M. Furuya and L.G.Q. Pinto, 2004. Digestibilidade aparente da matéria seca e da proteína bruta e a energia digestível de alguns alimentos alternativos pela tilápia do Nilo (Oreochromis niloticus). Acta Scientiarum Anim. Sci., 26: 329-337, 2004. DOI: $10.4025 /$ actascianimsci.v26i3.1798

Radecki, S.V. and E.R. Miller, 1990. Triticale. In: Nontraditional Feed Sources for Use in Swine Production, Thacker, P.A. and R.N. Kirkwood, (Eds.), pp: 493-493.

Rakshit, K.D., J. Darukeshwara, K. RathinaRaj, K. Narasimhamurthy and P. Saibaba et al., 2008. Toxicity studies of detoxified Jatropha meal (Jatropha curcas) in rats. Food Chem. Toxicol., 46: 3621-3625. DOI: 10.1016/j.fct.2008.09.010

Rostagno, H.S., L.F.T. Albino, J.L. Donzele, P.C. Gomes and R.F. Oliveira et al., 2005. Tabelas Brasileiras Para Aves e Suínos: Composição de Alimentos e Exigências Nutricionais. 1st Edn., UFV, Viçosa, pp: 186.

Serrano, V.O.S., 1989. Digestibilidade dos aminoácidos de suplementosprotéicosemsuínos, submetidosounão a anastomose íleo-retal. Dissertação (Mestradoem Zootecnia), Universidade Federal de Viçosa, Viçosa. 
Souza, C.F., J.J. Lucas and W.P.M. Ferreira, 2005. Biodigestão anaeróbia de dejetos de suínos sob efeito de três temperaturas e dois níveis de agitação do substrato: Considerações sobre a partida. Engenharia Agrícola, 25: 530-539.

Theodorou, M.K., B.A. Williams, M.S. Dhanoa, A.B. Mcallan and J. France, 1994. A simple gas production method using a pressure transducer to determine the fermentation kinetics of ruminant feeds. Anim. Feed Sci. Technol., 48: 185-197. DOI: 10.1016/0377-8401(94)90171-6
Waterman, P.G. and S. Mole, 1994. Analysis of Phenolic Plant Metabolites. 1st Edn., Wiley, Oxford, ISBN-10: 0632029692, pp: 248.

Zucchi, O.L.A.D. and V.F. Nascimento Filho, 1995. Caracterização qualitativa e quantitativa de elementos, pela técnica de fluorescência de raios X, em suplementos minerais para animais. I. Dispersão de comprimento de onda. Pesquisa Agropecuária Brasileira, 30: 1427-1439. 